\title{
First report of onion yellow dwarf virus in Ukraine
}

\section{Halyna Snihur $^{1} \cdot$ Tetiana Shevchenko $^{1} \cdot$ Khrystyna Sherevera $^{1} \cdot$ Irena Budzanivska ${ }^{1} \cdot$ Oleksiy Shevchenko $^{1}$ (i)}

Received: 28 February 2019 / Accepted: 4 June 2019 / Published online: 17 June 2019

(C) Società Italiana di Patologia Vegetale (S.I.Pa.V.) 2019

Keywords Onion yellow dwarf virus $\cdot$ garlic $\cdot$ potyvirus $\cdot$ Ukraine

During the last two years, large-scale production of garlic led to wide occurrence of virus-like symptoms on Allium sativum plants in Ukraine. In spring 2018, we collected garlic plants exhibiting yellowing, leaf mosaic, stunting and wilting from four regions of the country (Kyiv, Poltava, Cherkassy and Vinnytsia). Transmission electron microscopy of plant sap confirmed the presence of filamentous virions $(720-820 \times$ $16 \mathrm{~nm}$ ) typical of Potyvirus genus.

Onion yellow dwarf virus (OYDV) is one of the potyviruses infecting garlic in many countries including eastern EU states (Vončina et al. 2016), but was never reported from Ukraine. Using double-antibody sandwich enzymelinked immunosorbent assay with virus-specific antibodies (Loewe Biochemica, Germany), OYDV was detected in $63 \%$ of samples from all four screened regions of Ukraine.

Using OYDV coat protein-specific primers (Parrano et al. 2012), partial nucleotide sequence of one of the OYDV isolates (OYDV_UA_2018_vinn collected from Vinnytsia region) was amplified, sequenced and deposited in GenBank database (Accession number MK177281).

Oleksiy Shevchenko

alexshevchenko@ukr.net

1 Virology Department, ESC "Institute of Biology and Medicine", Taras Shevchenko National University of Kyiv, 64/13 Volodymyrska Street, Kyiv 01601, Ukraine
Phylogenetic analysis of OYDV_UA_2018_vinn showed the partial sequence to be distinct from any published sequence, with highest identity of $89 \%$ to Chinese OYDV isolates Yuhang (AJ510223) and YH1 (AJ292231), and lower identity to other Chinese isolates (AJ307033, AJ409309, and AJ409312) and other isolates of worldwide origin. This is the first report of OYDV in Ukraine, where occurrence was found to be widespread.

\section{References}

Parrano L, Afunian M, Pagliaccia D, Douhan G, Vidalakis G (2012) Characterization of viruses associated with garlic plants propagated from different reproductive tissues from Italy and other geographic regions. Phytopathol Mediterr 51(3):549-565

Vončina D, Ćurić K, Fabek S, Toth N (2016) First report of Onion yellow dwarf virus, Leekyellow stripe virus and Garlic common latent virus on garlic in Croatia. Plant Dis 100(3):656-656

Publisher's note Springer Nature remains neutral with regard to jurisdictional claims in published maps and institutional affiliations. 